\title{
Global left ventricular function quantification with CMR 4D Flow
}

\author{
Raluca G Saru" ${ }^{1 *}$ Kevin Wanambiro', Albert Hsiao², Sara Boccalini', Adriaan Coenen', Ricardo Budde, \\ Piotr Wielopolski ${ }^{1}$, Shreyas Vasanawala ${ }^{3}$, Jolien Roos-Hesselink', Koen Nieman ${ }^{1}$ \\ From 19th Annual SCMR Scientific Sessions \\ Los Angeles, CA, USA. 27-30 January 2016
}

\section{Background}

4D MR flow is a rapidly evolving technique, offering both anatomical and functional information in just a single acquisition and if successful, in the future, the 4D flow sequence should replace the 2D MR sequences. The purpose of this study is to use the anatomical information from the $4 \mathrm{D}$ flow sequence to assess the global left ventricular function and compare these results with the ones obtained from standard cine acquisitions.

\section{Methods}

Between September 2014 and February 2015, we prospectively included 22 consecutive adult patients (4 females, mean age 39 years) planned for CMR with a clinical indication for contrast administration. The 4D flow raw data sets were uploaded to a dedicated webbased software application (Arterys Inc., San Francisco, CA, USA).

Images were reconstructed in 20 cardiac temporal phases separately with a compressed sensing algorithm. The end-diastolic, end-systolic and stroke volumes and ejection fraction were measured by CMR 4D flow and compared against cine CMR measurements.

\section{Results}

The mean end-diastolic, end-systolic stroke volumes and ejection fraction were $163( \pm 30) \mathrm{ml}, 77( \pm 34) \mathrm{ml}$, $85( \pm 17) \mathrm{ml}$ and $54( \pm 11) \%$ respectively for CMR 4D flow and $182( \pm 50) \mathrm{ml}, 89( \pm 42) \mathrm{ml}, 93( \pm 18) \mathrm{ml}$, 53 ( \pm 10$) \%$ respectively for cine CMR. The Pearson's correlations between CMR 4D flow and CMR were 0.93, 0.96, 0.77 and 0.93 for end-diastolic, end-systolic, stroke volumes and ejection fraction respectively.

${ }^{1}$ Radiology and Cardiology, Erasmus MC, Rotterdam, Netherlands Full list of author information is available at the end of the article
When applying a threshold of $50 \%$ for ejection fraction, 21 out of 22 patients were correctly classified.

\section{Conclusions}

In this study we showed that global left ventricular function can be quantified accurately using CMR 4D flow imaging analysed using a cloud based software.

\section{Authors' details}

'Radiology and Cardiology, Erasmus MC, Rotterdam, Netherlands. ${ }^{2}$ University of california, San Diego, CA, USA. ${ }^{3}$ Stanford University, Palo Alto, CA, USA.

Published: 27 January 2016

doi:10.1186/1532-429X-18-S1-P308

Cite this article as: Saru et al:: Global left ventricular function

quantification with CMR 4D Flow. Journal of Cardiovascular Magnetic Resonance 2016 18(Suppl 1):P308.

Submit your next manuscript to BioMed Central and take full advantage of:

- Convenient online submission

- Thorough peer review

- No space constraints or color figure charges

- Immediate publication on acceptance

- Inclusion in PubMed, CAS, Scopus and Google Scholar

- Research which is freely available for redistribution

Submit your manuscript at www.biomedcentral.com/submit
C Biomed Central 